\title{
Aerosol events in the broader Mediterranean basin based on 7-year (2000-2007) MODIS C005 data
}

\author{
A. Gkikas ${ }^{1}$, N. Hatzianastassiou ${ }^{1,2}$, and N. Mihalopoulos ${ }^{3}$ \\ ${ }^{1}$ Laboratory of Meteorology, Department of Physics, University of Ioannina, 45110 Ioannina, Greece \\ ${ }^{2}$ Foundation for Research and Technology-Hellas, Heraklion, Crete, Greece \\ ${ }^{3}$ Environmental Chemical Processes Laboratory, Dept. of Chemistry, University of Crete, 71300 Heraklion, Crete, Greece
}

Received: 31 March 2009 - Revised: 22 July 2009 - Accepted: 14 August 2009 - Published: 23 September 2009

\begin{abstract}
Aerosol events (their frequency and intensity) in the broader Mediterranean basin were studied using 7-year (2000-2007) aerosol data of optical depth (AOD at 550 nm) from the MODerate Resolution Imaging Spectroradiometer (MODIS) Terra.

The complete spatial coverage of data revealed a significant spatial variability of aerosol events which is also dependent on their intensity. Strong events occur more often in the western and central Mediterranean basin (up to 14 events/year) whereas extreme events (AOD up to 5.0) are systematically observed in the eastern Mediterranean basin throughout the year. There is also a significant seasonal variability with strong aerosol events occurring most frequently in the western part of the basin in summer and extreme episodes in the eastern part during spring. The events were also analyzed separately over land and sea revealing differences that are due to the different natural and anthropogenic processes, like dust transport (producing maximum frequencies of extreme episodes in spring over both land and sea) or forest fires (producing maximum frequencies in strong episodes in summer over land). The inter-annual variability shows a gradual decrease in the frequency of all aerosol episodes over land and sea areas of the Mediterranean during the period 2000-2007, associated with an increase in their intensity (increased AOD values). The strong spatiotemporal variability of aerosol events indicates the need for monitoring them at the highest spatial and temporal coverage and resolution.
\end{abstract}

Keywords. Atmospheric composition and structure (Aerosols and particles; Pollution - urban and regional)

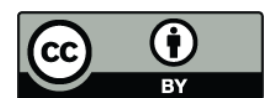

Correspondence to: N. Hatzianastassiou (nhatzian@cc.uoi.gr)

\section{Introduction}

In the last two decades there is a strong scientific interest regarding the role of aerosols for the Earth's climate and associated changes. Aerosol particles are very important to the Earth-atmosphere climate system playing a crucial role in cloud and precipitation processes, air quality and climate. Cloud composition, precipitation, the hydrological cycle, radiation budget and the atmospheric circulation systems are all affected by both radiative and microphysical impacts of aerosols (Rosenfeld et al., 2008). The Technical Summary of Working Group One in the IPCC Fourth Assessment Report (2007) states that changes in aerosols may have affected precipitation and other aspects of the hydrologic cycle more strongly than other anthropogenic forcing agents. For example, aerosols were reported to modulate the hydrological cycle (e.g. Jacobson, 2001; Ramanathan et al., 2001; Kaufman et al., 2002) or to spinning-down the tropical water cycle and weakening the Asian monsoons (e.g. Lau et al., 2006). Therefore, given the importance of aerosols, it is certainly worth to study the so-called "aerosol events" or "aerosol episodes", namely conditions of unusual high concentrations of aerosol over a specific place of world at a given time. Due to important temporal and spatial variability of aerosols, their events must be investigated at the highest spatial and temporal coverage and resolution, for example on a daily basis and at geographical cell level. Complete spatial resolution is only ensured by satellite-based measurements, also enabling daily temporal resolution. Surface (station) measurements provide more fine temporal resolution (hourly) but they do not provide complete spatial coverage.

The broader Mediterranean basin is a unique area in terms of aerosols and climate change. It is one of the areas with the highest aerosol optical depths in the world (Husar et al., 1997; Ichoku et al., 2002) and maximum direct radiative

Published by Copernicus Publications on behalf of the European Geosciences Union. 
forcing values (Hatzianastassiou et al., 2004, 2007) due to the accumulation of aerosols, which is favoured by meteorological conditions, small cloudiness and prolonged exposure to solar radiation. Moreover, Mediterranean is a climatically sensitive region (IPCC, 2007), that includes desertification threatened coastal and/or island areas (e.g. North Africa, Crete island). IPCC (2007) reports that future climate changes may add to existing problems of desertification, water scarcity and food production, while also introducing new threats to human health, ecosystems and national economies of countries. These, together with the fact that aerosols crucially affect precipitation (Lohmann, 2008; Rosenfeld et al., 2008) clearly show that studying aerosol events in Mediterranean basin is of special importance since these events deliver massive amounts of aerosol matter in the region's atmosphere for long periods, especially in dry period.

In the past, a number of studies dealt with aerosol events in the Mediterranean basin, but these were performed for specific aerosol types, such as dust (Dayan et al., 1991; Moulin et al., 1997; Husar et al., 2001; Tsidulko et al., 2002; Balis et al., 2003; Collaud Coen et al., 2004; Kubilay et al., 2003; Rodríguez et al., 2004; Lyamani et al., 2005; Papayanis et al., 2005; Athanassiadou et al., 2006; Cachorro et al., 2006; Pérez et al., 2006; Sodemann et al., 2006; Zhang et al., 2006; Toledano et al., 2007; Meloni et al., 2008; Sciare et al., 2008; Salvador et al., 2008), fine pollution (Kukkonen et al., 2005), forest fires (Niemi et al., 2005; Pace et al., 2005) or sea-salt aerosols (Marenco et al., 2007). The majority of these studies were performed at specific locations using mainly ground-based measurements. Thus it is very important to have a complete picture of aerosol events over the entire Mediterranean basin during a long enough time period. This is achieved in the present study by using quality measurements taken with the MODerate resolution Imaging Spectroradiometer (MODIS) instrument on board the NASA Terra spacecraft. Collection 005 Level-3 gridded daily data of aerosol optical depth (AOD) are used with horizontal resolution $1^{\circ} \times 1^{\circ}$ latitude-longitude, from March 2000 to February 2007 (complete 7-year study period) over the Mediterranean basin including land and ocean areas extending from $29^{\circ} \mathrm{N}$ to $47^{\circ} \mathrm{N}$ and from $11^{\circ} \mathrm{W}$ to $39^{\circ} \mathrm{E}$. The scope of this study is to identify the main characteristics of aerosol episodes, namely their frequency and intensity on different temporal (from monthly to annual) and spatial (local to regional) scales. Apart from the seasonal, the interannual variability of aerosol episodes is also examined and their tendencies over the study period are investigated.

\section{Data and methodology}

\subsection{MODIS aerosol optical depth data}

The aerosol data used are part of the MODIS Terra Level3 daily gridded atmospheric data product (MOD08_D3) and were acquired from the MODIS web site ftp://ladsweb. nascom.nasa.gov/. The first MODIS instrument was launched on board the Terra satellite on 18 December 1999, with daytime equator crossing at 10:30 a.m., as part of the NASA's Earth Observing System (EOS) mission. MODIS with its $2330 \mathrm{~km}$ viewing swath provides almost daily global coverage. Since February 2000, MODIS has continuously acquired measurements at 36 spectral bands between 0.415 and $14.235 \mu \mathrm{m}$ with spatial resolution of $250 \mathrm{~m}, 500 \mathrm{~m}$ and $1000 \mathrm{~m}$. The retrieval of aerosol data by MODIS is performed with special algorithms (see e.g. Kaufman et al., 1997, 2001; Tanré et al., 1997; Levy et al, 2003; Remer et al., 2005), which are different over land and ocean because of differences in surface characteristics. The MODISderived aerosol properties have been extensively validated against AERONET Sun-photometer measurements. The accuracy of the algorithm for MODIS Collection 004 AOD is $\pm 0.05 \pm 0.2 \times A O D$ over land (Chu et al., 2002), and $\pm 0.03 \pm 0.05 x$ AOD over ocean (Remer et al., 2002). Recently, the Collection 005 MODIS aerosol data were released, marked by significant improvements in the retrieval algorithm leading to better agreement with surface-based AERONET measurements (Remer et al., 2006; Levy et al., 2007; Papadimas et al., 2009). In this study, we used the Collection 005 MODIS-Terra AOT data at $\lambda=550 \mathrm{~nm}$. The data used are stored in MODIS Level 3 (MOD04L3) files, each corresponding to daily averages, and they are reported on a $1^{\circ} \times 1^{\circ}$ spatial resolution. These data provide daily statistics based on the original $500 \mathrm{~m}$ resolution data. Over the course of a day, MODIS views the same $1^{\circ}$-square (grid) with a large variety of view angles, which improves the accuracy of calculated flux (Remer and Kaufman, 2006) and aerosol retrievals. The daily data from the Terra satellite form a continuous time series from March 2000 to February 2007.

\subsection{Methodology}

In the literature there is no well defined methodology to identify aerosol events. Several researchers have used threshold values of aerosol optical properties parameters, mostly AOD, Ångström exponent and fine fraction, to identify aerosol episodes.

In the present study, the determination of aerosol events was based on AOD, which is a good measure of aerosol matter in the entire atmospheric column over a specific area on a given day. Thus, an aerosol event occurs in a specific day at a given location when AOD is larger than a critical value constituting a threshold (cut-off) AOD level ( $\left.\mathrm{AOD}_{\text {Threshold }}\right)$. By setting critical AOD level, equal to the mean AOD ( $\overline{\mathrm{AOD}})$, averaged over the whole study period, aerosol events can be defined, for each location, when AOD is larger than $\overline{\mathrm{AOD}}$ plus one, two, three and four standard deviation $\left(\sigma_{\mathrm{AOD}}\right)$ from $\overline{\mathrm{AOD}}$

$\mathrm{AOD}_{\text {Threshold }}=\overline{\mathrm{AOD}}+i \times \sigma_{\mathrm{AOD}}, \quad$ with $\quad i=1,2,3,4$ 

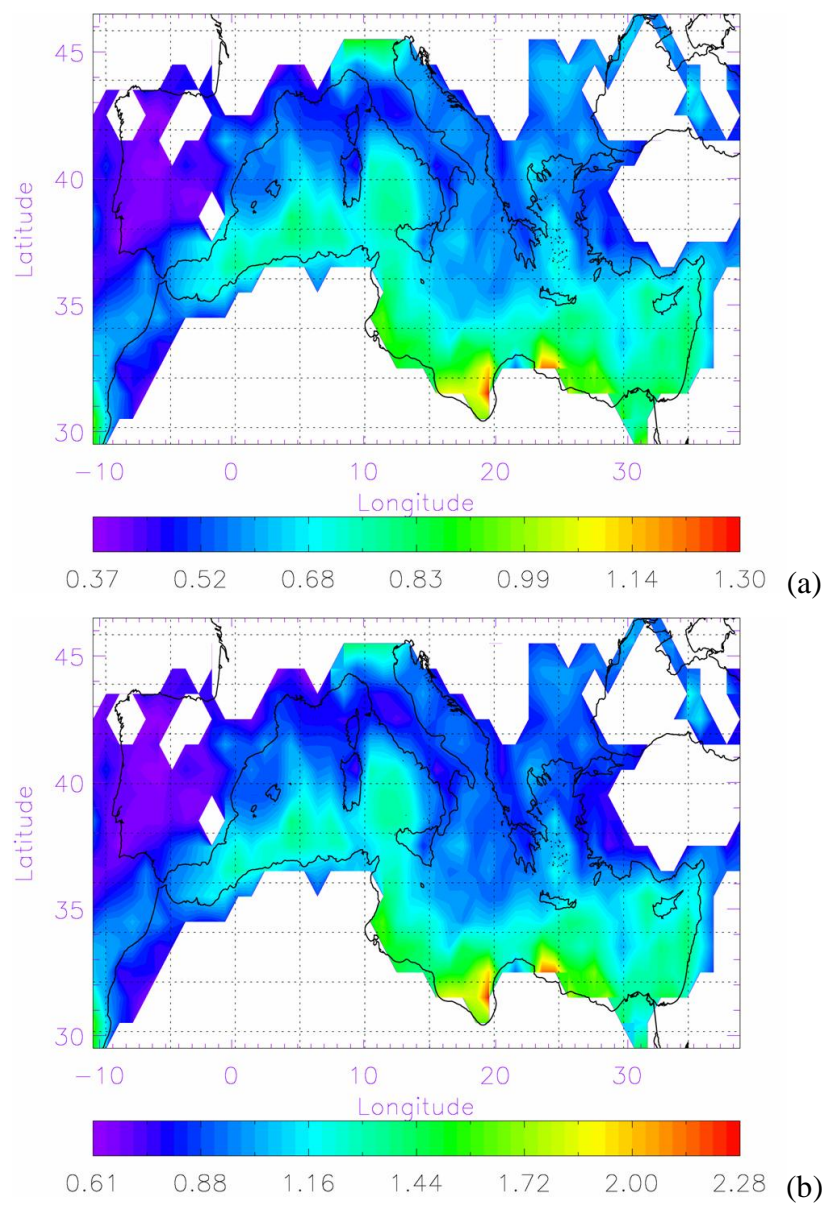

Fig. 1. Geographical distribution of the threshold AOD values of aerosol episodes over the broader Mediterranean basin for the period 2000-2007 for: (a) strong and (b) extreme aerosol episodes. The white areas correspond to $1^{\circ} \times 1^{\circ}$ longitude-latitude geographical cells with less than $50 \%$ data coverage.

In the present study, whenever

$\overline{\mathrm{AOD}}+2 \times \sigma_{\mathrm{AOD}} \leq \mathrm{AOD}<\overline{\mathrm{AOD}}+4 \times \sigma_{\mathrm{AOD}} \ldots \quad$ then a strong aerosol episode is defined, whereas extreme aerosol episodes occur if $\mathrm{AOD} \geq \overline{\mathrm{AOD}}+4 \times \sigma_{\mathrm{AOD}}$. The geographical distribution of AOD thresholds for the two types of aerosol episodes is given in Fig. 1, and they are equal up to 1.3 and 2.3 for strong and extreme aerosol episodes, respectively. Following our methodology other types of aerosol episodes, e.g. weak ones, can be also determined. Note that other methodologies can be applied as well, for example by setting a standard $\mathrm{AOD}_{\text {Threshold }}$ for the entire Mediterranean basin. Such methods have their own advantages and disadvantages with respect to the dynamical methodology applied here. The sensitivity of aerosol episodes to the selected methodology was assessed by comparing the frequency of episodes obtained based on the two methodologies. It was found that the use of the common $\mathrm{AOD}_{\text {Threshold }}$ for the entire study region resulted in more aerosol episodes over northern Africa
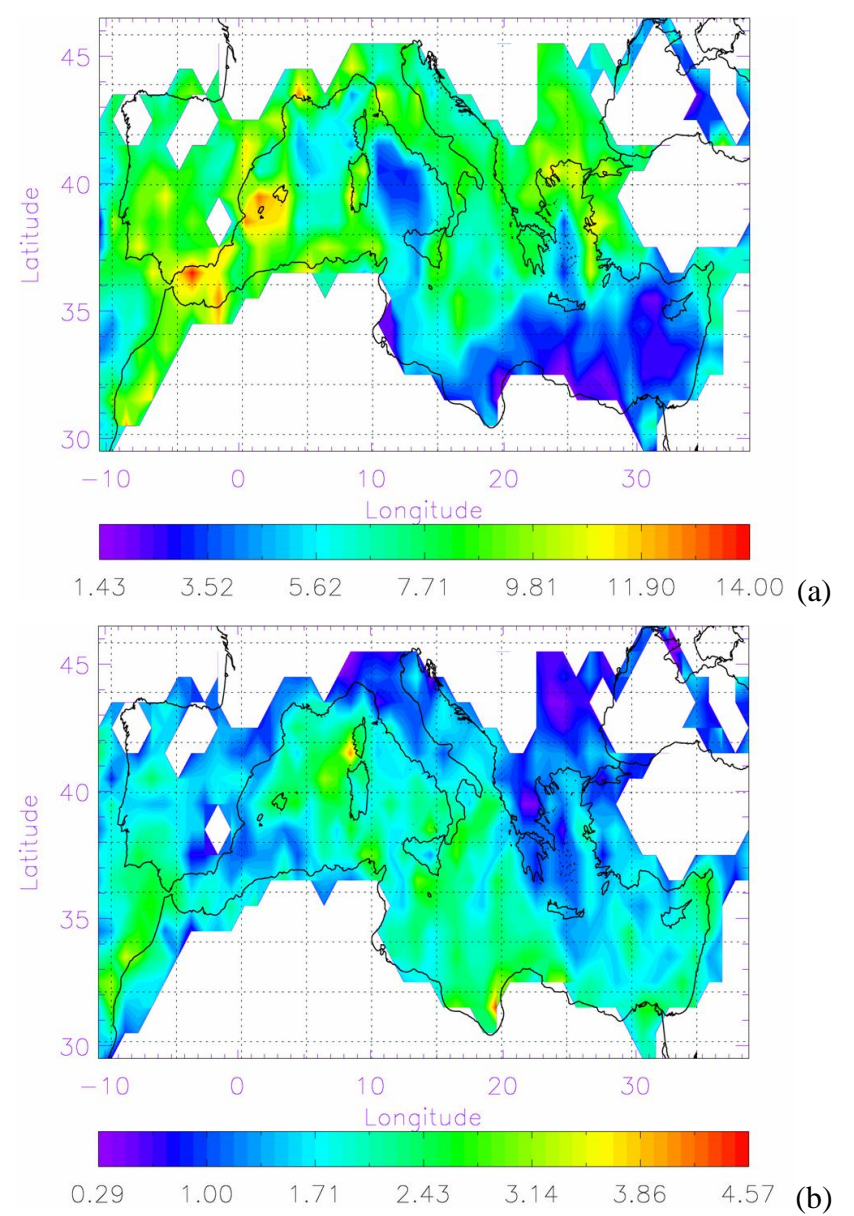

Fig. 2. Geographical distribution of the frequency of aerosol episodes (episodes/per year) over the broader Mediterranean basin for the period 2000-2007: (a) for strong aerosol episodes and (b) for extreme aerosol episodes. The white areas correspond to $1^{\circ} \times 1^{\circ}$ longitude-latitude geographical cells with less than $50 \%$ data coverage.

and its coasts, and less episodes in the northern part of the Mediterranean Sea thus producing a "bias" towards the intense aerosol sources, namely dust. On the other hand the applied methodology here is useful for a subjective consideration of aerosol episodes regarding their magnitude which is the common case. $\overline{\mathrm{AOD}}$ and $\sigma_{\mathrm{AOD}}$ values for each geographical cell of the Mediterranean basin were computed from the time series of daily AOD values. Subsequently, aerosol episodes were identified by comparing AOD for each day of the study period (1 March 2000 to 28 February 2007) with the corresponding $\mathrm{AOD}_{\text {Threshold. The }}$ the frequency, intensity (and duration) of aerosol episodes were computed for each month and year as well as for the entire study period. Note that the results were obtained based on the criterion that at least $50 \%$ of the total 2556 daily AOD values from 1 March 2000 to 28 February 2007 were available. 


\section{Results}

\subsection{Geographical distributions}

The seven year (2000-2007) mean spatial distribution of the frequency of strong and extreme aerosol episodes over the study region is shown in Fig. 2. This is the first time that such information is obtained on a complete spatial scale over the broader Mediterranean basin, as similar past analyses were limited to specific locations. Note that the results are referred to aerosol episodes with no regard to aerosols type for example dust, biomass burning or sea-salt.

There is a significant spatial variability of aerosol episodes over the Mediterranean basin with frequencies ranging up to about 14 strong or 5 extreme episodes per year (Fig. 2a). In addition, there is a clear difference between the western and eastern parts of the Mediterranean basin, the former being subject more often to aerosol episodes than the latter. In almost all land and sea areas westward of Sardinia and Corsica up to Portugal and Morocco's west coasts 6-14 strong aerosol episodes/year are observed. On the contrary, in the central and eastern parts of the basin no more than 10 strong aerosol episodes/year are found.

The results concerning aerosol episodes are in general quite different than those referring simply to aerosol loads. Thus, the frequency of aerosol episodes has a totally different spatial distribution than aerosol load. For example, the inner Iberian peninsula, which is characterized by small AODs with respect to the entire Mediterranean basin (Papadimas et al., 2008) is observed to have high frequencies of strong episodes. The obtained features of aerosol episodes can be explained by taking into account that an episode is related to unusual high aerosol load, i.e. larger than its mean levels. Therefore, it is possible that an area is characterized by regularly high aerosol loads but with only few cases with AOD larger than $\mathrm{AOD}_{\text {Threshold }}$ (aerosol episodes). Nevertheless, there are also some regions (for example southeast Spain and Alboran basin between Morocco and Spain) that exhibit both large long-term AODs and high frequencies of aerosol episodes.

The importance of defining threshold AOD levels is shown by the difference between the frequencies of strong and extreme aerosol episodes (Fig. 2a and b). As expected, the frequencies of extreme aerosol episodes are smaller $(<5$ episodes/year) than those for strong episodes. A region can exhibit large frequency of strong episodes but only a small frequency of extreme episodes, as for example the western Mediterranean basin. The most frequent extreme aerosol episodes are observed in the central Mediterranean basin, off the coasts of Libya and Tunisia up to the Ionian Sea, as well as in the Tyrrhenian Sea. Also, the coasts of the eastern Mediterranean basin are subject to relatively frequent intense aerosol episodes (up to about 3 episodes/year).

In general, land areas are characterized by clearly less extreme aerosol episodes (generally $<2$ episodes/year) than sea surfaces and coasts of the Mediterranean basin, opposite to what happens with strong aerosol episodes (Fig. 2a). This can be explained by considering that an aerosol episode takes place under effective long- or medium range transport, excessive local emissions due to anthropogenic or natural activities or because of gradual accumulation of aerosols in the atmosphere under dry atmospheric conditions. In general, maritime regions have smaller AOD values than continental ones (Andreae, 2009), thus for a given high aerosol load (under intense transport conditions) they have a better chance to undergo extreme aerosol episodes. Moreover, Mediterranean maritime areas are closer to the northern African coasts than continental areas (e.g. Iberian, Italian and Balkan peninsulas) and thus under the direct influence of Saharan dust. On the other hand, land areas due to their distance undergo weakened exports of Saharan dust and thus mainly strong (and not extreme) aerosol episodes occur. Overall, the observed differences in the frequency of aerosol episodes between Mediterranean land and sea areas are explained by their distance from the main aerosol sources in the study area. For example, the Mediterranean Sea is closer to dust sources than European continental areas. Nevertheless, the above differences between land and sea aerosol episodes have to be assessed also keeping in mind that the uncertainty of MODIS AOD is larger over land than sea (see Sect. 2.1). Dust (mainly from Sahara and less from Middle-East) is the most important source of particulate matter in the Mediterranean basin and its transport is usually associated with large AODs (e.g. Barnaba and Gobi, 2004). Therefore, extreme aerosol episodes should be associated with dust. This is also shown by the agreement between the maximum frequency of extreme aerosol episodes in the central Mediterranean basin found in this work (Fig. 2b) and the largest average dust optical depth in the central basin reported in the literature, for example by Moulin et al. (1998) based on 11-year Meteosat data or by Papadimas et al. (2008) based on 6-year MODIS data. Other sources of aerosol are sea-salt, biomass burning (forest fires) and industrial or other anthropogenic activities, but they are all, with the exception of sea-salt, clearly less important than dust while pollution aerosol plumes are often associated with lower AODs (Barnaba and Gobi, 2004). Hence, strong aerosol episodes should be rather associated to transport or emission of such aerosols.

The frequency of aerosol episodes has a significant seasonal variability (Fig. 3). To better understand the seasonal variability of episodes the most import meteorological features of the Mediterranean have to be considered. In the western basin, Sahara dust outbreaks are more frequent during summer and in lesser extend in winter, while in the eastern basin during spring and autumn (e.g. Moulin et al., 1998; Kalivitis et al., 2007). During winter time anticyclonic situations associated with intense breeze action along the Western Mediterranean coast favors the accumulation of pollutants especially above the Iberian penisnsula (Millán et al., 1997; Rodríguez et al., 2002; Pérez et al., 2004). On the other 

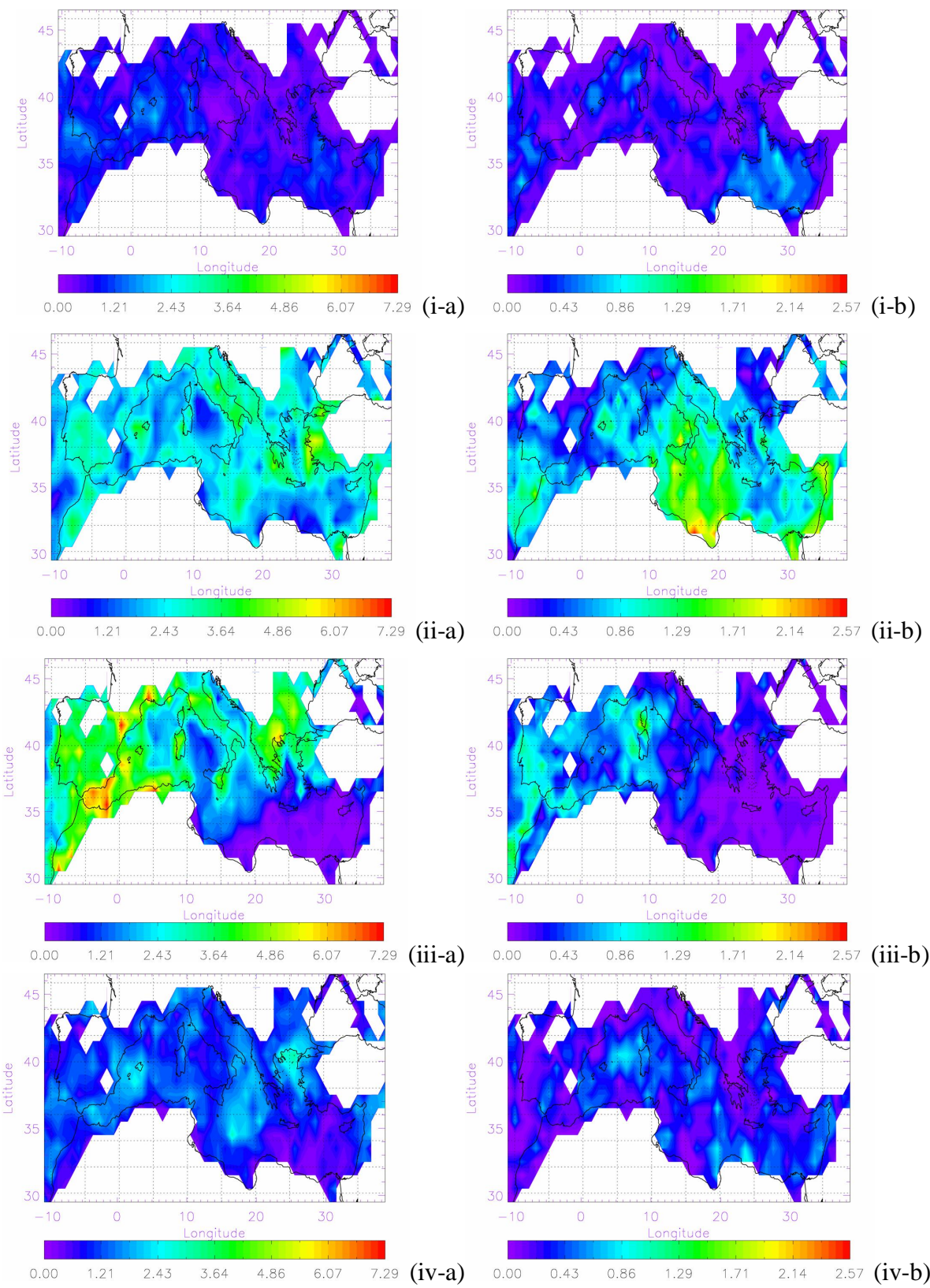

Fig. 3. As in Fig. 2 but for: (i) winter, (ii) spring, (iii) summer and (iv) autumn. Columns (a) and (b) show the results for strong and extreme aerosol events, respectively.

hand during summer the persistent northerly winds, called "Etesians", occur in the Eastern Mediterranean favouring the transport of particles from urban areas of central and Eastern Europe as well as from areas with intense biomass burning (Balis et al., 2003; Sciare et al., 2008).

The strong episodes occur most frequently in summer whereas the extreme episodes in spring (Fig. 3iii-a, and 3ii-b, respectively). Moreover, while the most frequent strong episodes (7.3 episodes/year) are observed during sum- mer in the western Mediterranean basin (especially in SE Spain and Alboran basin) extreme aerosol episodes occur most frequently ( 2.6 episodes/year) during spring in the central and eastern Mediterranean basin. Apart from summer, strong aerosol episodes are also marked quite often $(6$ episodes/year) during spring mainly in central and eastern parts of the basin. However, the domination of summer and spring maximum frequencies of aerosol episodes in the western and central parts of the Mediterranean basin is projected 


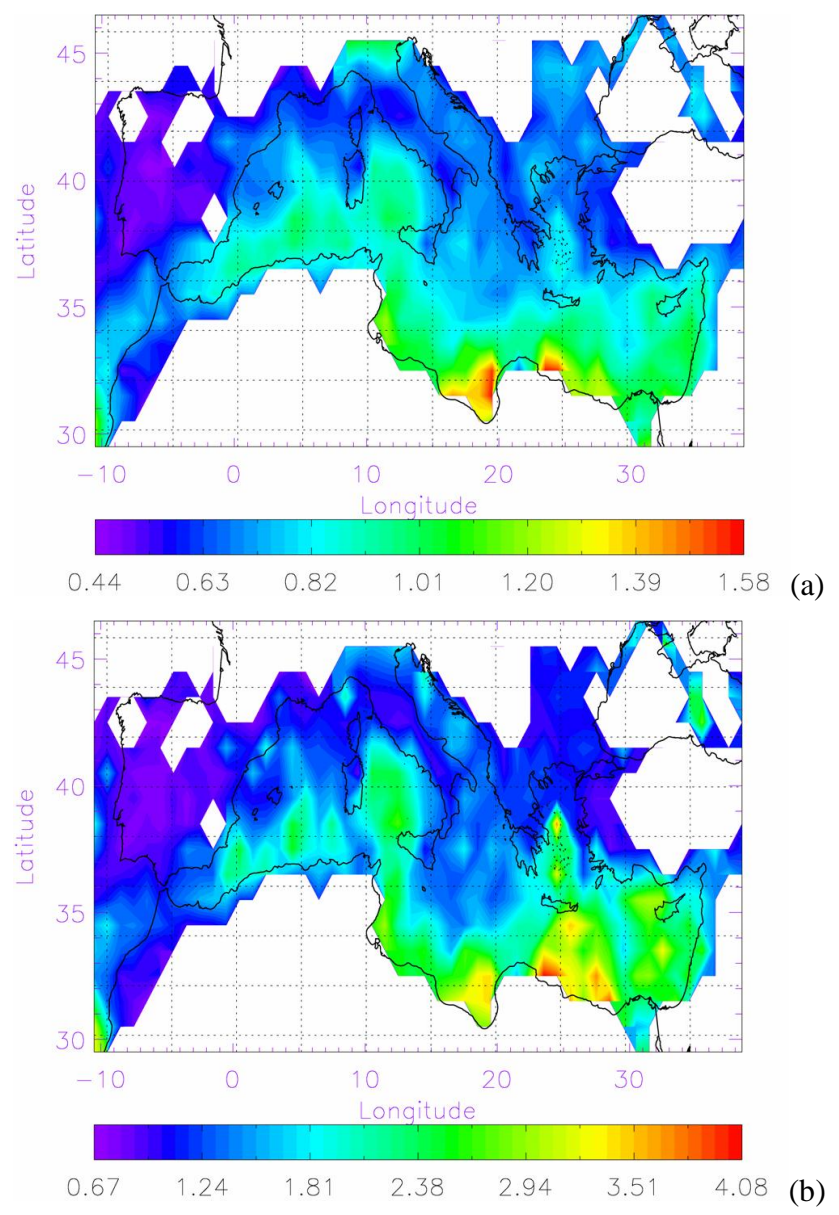

Fig. 4. Geographical distribution of the intensity of aerosol episodes (by means of AOD) over the broader Mediterranean basin for the period 2000-2007: (a) for strong aerosol episodes and (b) for extreme aerosol episodes.

on the annual mean frequency distributions (Fig. 2). Note that the features of aerosol episodes (Fig. 3a, b) are fully consistent with those of dust transport in the Mediterranean from Africa maximizing during spring in the eastern basin and during summer in the western one. The frequency of aerosol episodes is thus dictated by the climatology of depressions affecting North Africa determining the frequency of dust outbreaks over the Mediterranean. Precipitation appears to be an important factor explaining both the seasonal east-west shift in transport location and the south-north gradients of dust concentrations over the Mediterranean, and the subsequent aerosol episodes. Finally the meteorological conditions clearly explain the aerosol episodes off the western coast of the Iberian peninsula during winter (Fig. 3a-i).

The intensity of aerosol episodes, by means of AOD, is illustrated on an annual and seasonal basis in Figs. 4 and 5 , respectively. There is a very clear south-to-north gradient showing that the intensity of aerosol episodes is gradually decreasing leaving the African coasts. During the days of strong and extreme aerosol episodes the mean $\mathrm{AOD}$ at $550 \mathrm{~nm}$ reaches high-to-extreme values of about 1.6 in the Libyan Sea, and 4.1 in the Levantine Sea, respectively. On the contrary, AOD values over continental areas do not exceed $\approx 1.0$. This is another proof of the role of African dust transport on aerosol episodes features. Though strong aerosol episodes occur most frequently in the western Mediterranean basin (Fig. 2a) they are characterized by smaller intensities. It is also interesting that the eastern part of the Mediterranean basin undergoes the most intensive extreme aerosol (dust) episodes (Fig. 4b) though these are less frequent than those observed in the central basin (Fig. 2b). Even stronger aerosol episodes are found on a seasonal basis (Fig. 5) with AOD values at $550 \mathrm{~nm}$ equal up to 2.0 and 5.0 for strong and extreme episodes, respectively.

\subsection{Intra-annual and inter-annual variability}

Apart from climatological and geographical distributions of features of aerosol episodes, the seasonal and inter-annual variability was also studied. This was made possible as aerosol episodes are spatially resolved based on the complete geographical coverage ensured by the utilized MODIS data.

\subsubsection{Intra-annual variability}

The overall seasonal variability of strong and extreme aerosol episodes taking place separately over land and maritime (sea) areas in the eastern, western, central and the whole Mediterranean basin as well as over both land and sea areas in each case, is shown in Fig. 6. For the entire Mediterranean basin (Fig. 6iv) spring and summer, i.e. the dry seasons, are periods that favor the occurrence of aerosol episodes accounting for about $71-72 \%$ of the total number of episodes, whereas the episodes are very rare (10-12\%) in winter due to large precipitation amounts. Though there is equivalence between spring and summer in terms of the frequency of strong aerosol episodes, there is a predominance of spring for extreme episodes that, as explained in the previous section, are mostly associated with dust transport from Africa in the eastern Mediterranean basin. Nevertheless, different patterns are found when examining the eastern, central and western parts (land and sea areas) of the basin separately. Thus, though strong aerosol episodes occur more frequently during spring than summer in the eastern Mediterranean basin, they occur with same frequencies during both seasons in the central part of the basin, whereas on the contrary they take place more frequently during summer in the western part. On the other hand, as far as it concerns the extreme aerosol episodes, these are found to occur much more frequently during spring than summer in the eastern and central parts of the Mediterranean basin (about $60 \%$ of total extreme episodes) but they occur with similar frequencies in the western part.

The frequency of aerosol episodes is also analyzed separately over land and sea areas. For the entire Mediterranean 

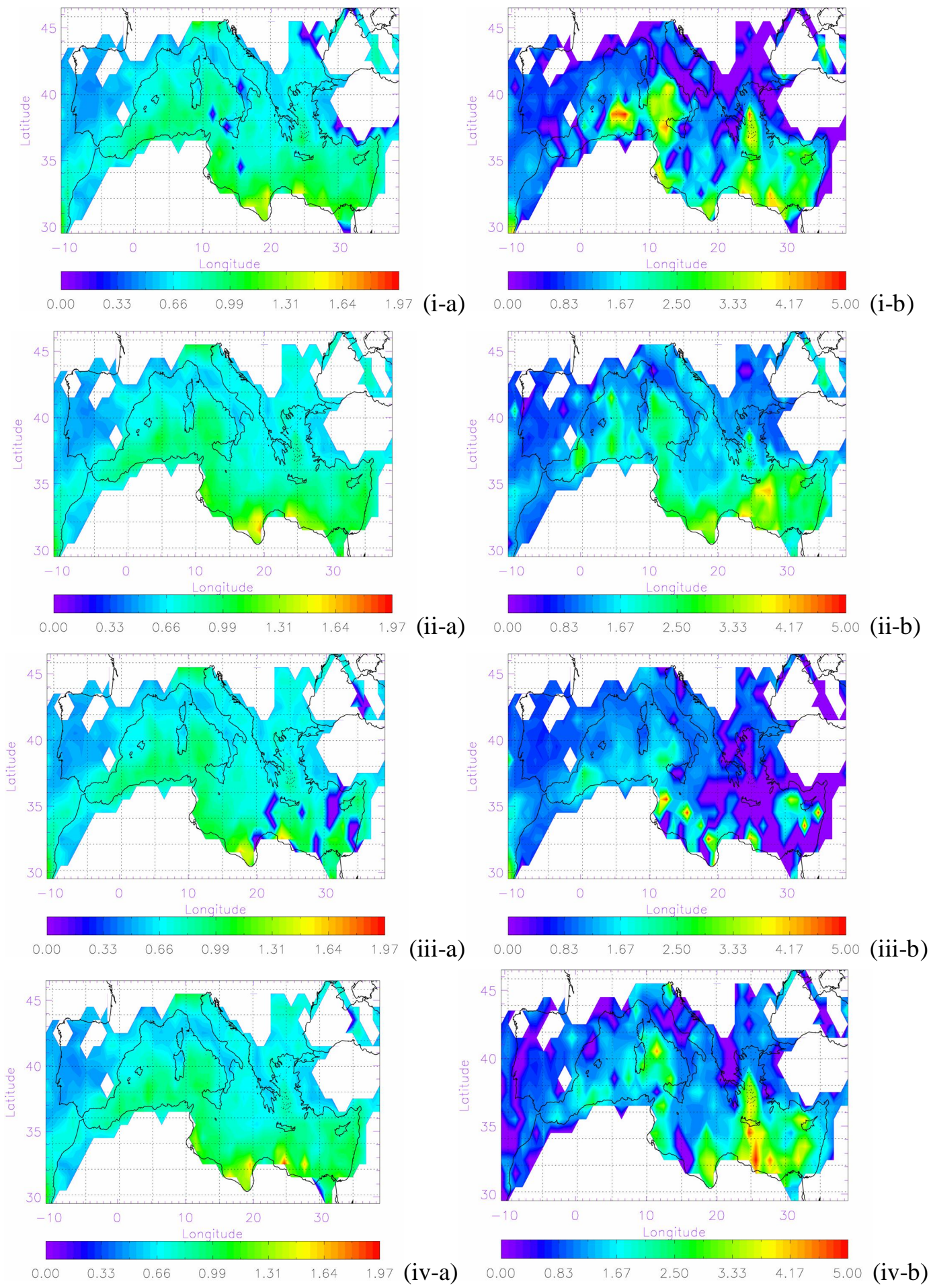

Fig. 5. As in Fig. 4 but for: (i) winter, (ii) spring, (iii) summer and (iv) autumn. Columns (a) and (b) show the results for strong and extreme aerosol events, respectively.

basin (Fig. 6iv) the predominance of spring and summer is valid for both sea and land areas. Nevertheless, the relative contribution of the two seasons is different as far as it concerns the strong episodes. Thus, although most of strong episodes (36.1\%) occurring over sea take place in spring, the reverse is valid for the episodes occurring over land areas of 

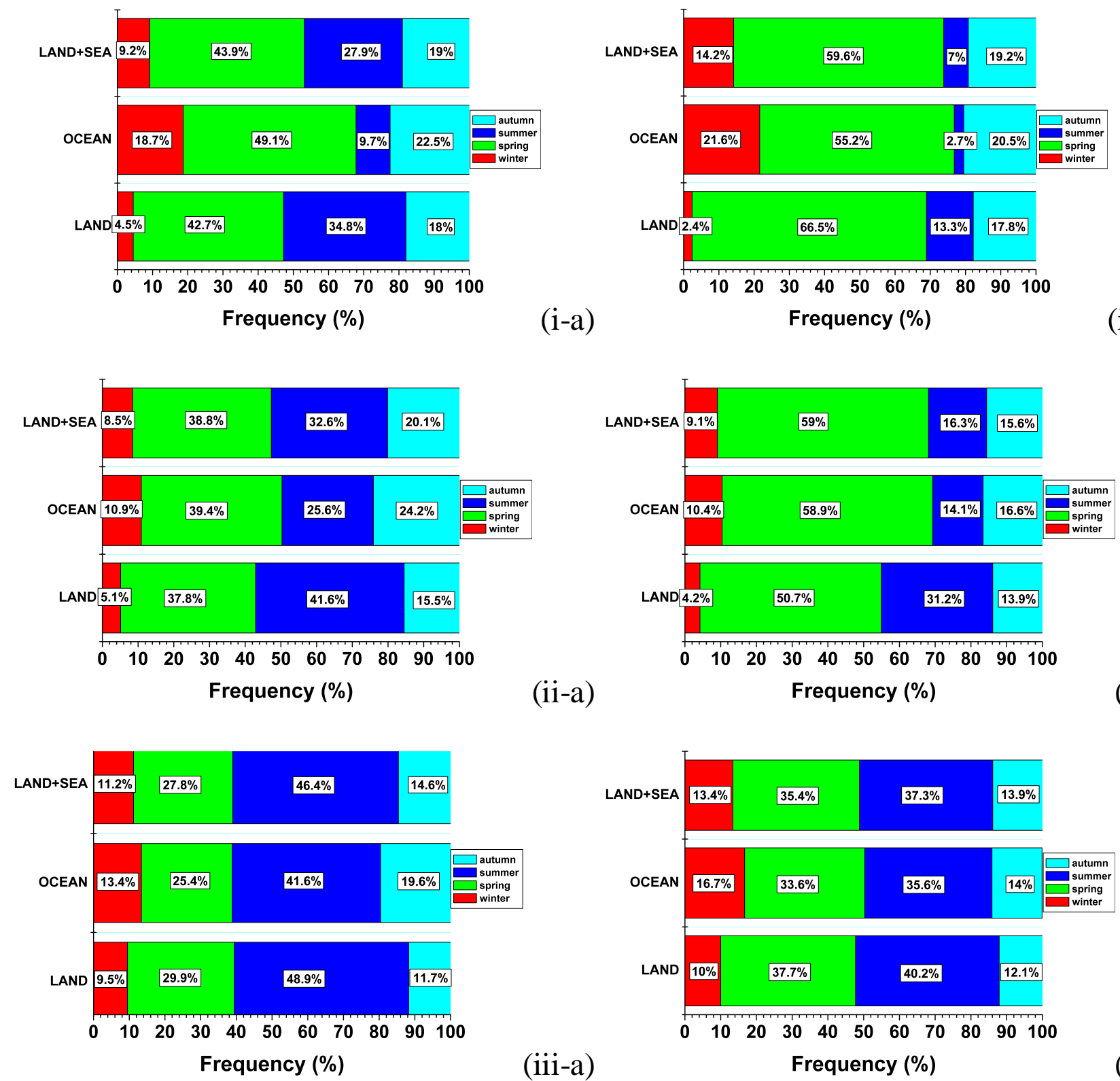

(iii-b)

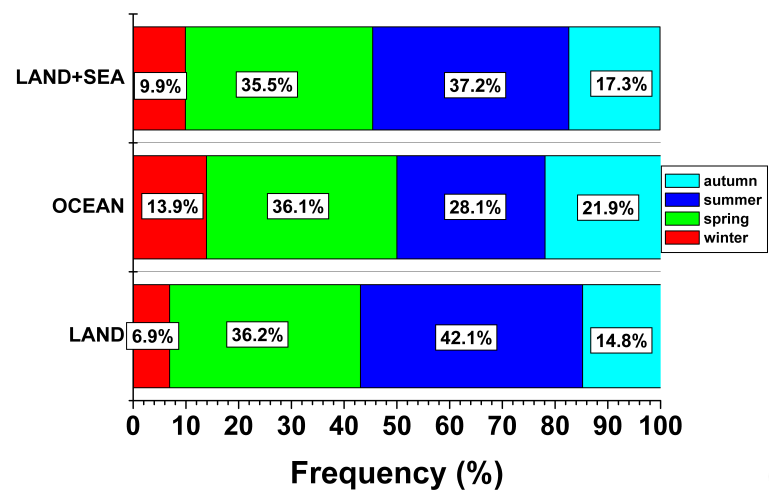

(iv-a)

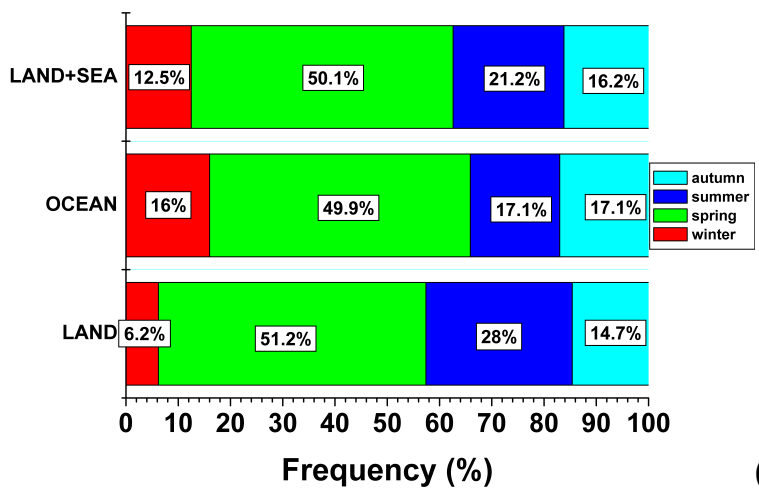

(iv-b)

Fig. 6. Seasonal distribution of the frequency of (a) strong and (b) extreme aerosol episodes over land, sea, and land+sea areas in the (i) eastern, (ii) central, (iii) western and (iv) whole Mediterranean basin during the period 2000-2007. 
the basin with $42 \%$ being observed in summer. Note that the above patterns are also valid for the eastern and central parts of the basin, but not for the western part where there is a predominance of summer episodes over both land and sea areas. The predominance of spring over summer aerosol episodes in sea Mediterranean areas is also valid for extreme episodes ( $50 \%$ for spring against $21 \%$ for summer). Nevertheless, the same, i.e. the predominance of spring, is also valid for extreme aerosol episodes over land, opposite to what is found for strong episodes over land areas. Moreover, there is a predominant appearance of extreme aerosol episodes in spring for the eastern and central parts of the basin (with frequencies as high as 67\%) against equivalent occurrences of extreme episodes in spring and summer in the western parts of the basin. Given that aerosol episodes are mainly due to dust, and that dust transport is a long-range process, it is expectable that the frequency of extreme aerosol episodes in the Mediterranean basin is higher during spring over both land and sea surfaces. The highest frequency of strong episodes over land areas (Fig. 6a) during summer, is an indication that these episodes probably originate in land areas either just around the Mediterranean Sea, so they are due to local emissions, or in remote land areas (other than extended deserts in southern parts of the basin, i.e. in Africa) and so they are due to long-range transport. These clues together with the fact that during summer a large number of forest fires occurs in Europe, and especially around the Black Sea and in northern Balkans and also in the Iberian peninsula (van der Werf et al., 2006; hotspots/fire map products from the NASA funded Fire Information for Resource Management System, FIRMS, http://maps.geog.umd.edu/firms/), suggest that the largest frequency of strong aerosol episodes over land in summer can be attributed, at least partly, to biomass burning and subsequent long-range transport leading to accumulation of aerosols (e.g. Balis et al., 2003; Sciare et al., 2008) facilitated by stable and dry atmospheric and synoptic conditions (Metaxas and Bartzokas, 1994). Especially, in case of biomass burning taking place within the geographic limits of the studied areas, as for example in the western basin, the predominance of aerosol episodes in summer is clear. However, other reasons for the largest frequency of strong aerosol episodes over land in summer can be also assessed. For example, during summer there is dust transport at elevated altitudes and thus high aerosol loadings can be accumulated over land and not over sea which is closer to dust African sources (see e.g. Amiridis et al., 2005; Kalivitis et al., 2007). Moreover, the largest frequency of strong aerosol episodes over land in summer can be also attributed to transport of dust from Africa that takes place mainly in the western, and less in the central, Mediterranean basin (see Fig. 2) under favorable synoptic conditions.

\subsubsection{Inter-annual variability and changes}

The complete spatial coverage by the MODIS AOD data allows us to examine the temporal variation of regional mean frequency of aerosol episodes. Given the identified differences in episodes over land and sea areas it is more important to examine the variation separately. Figure 7 gives the time series of monthly mean regional values of frequency and intensity of aerosol episodes for the broader Mediterranean region over the study period, separately over land and ocean. Note that the frequency numbers are normalized to be expressed in number of events per unit area $\left(1^{\circ} \times 1^{\circ}\right.$ or about $100 \mathrm{~km} \times 100 \mathrm{~km}$ ). In general, there is an annual cycle with double maxima in frequency in spring and summer, compared with minima during winter. The maxima in spring and summer are mainly associated with high desert dust loads in the central and eastern basin (see Sect. 2). In most cases the spring maximum frequency is primary and the summer maximum is secondary. Only for strong episodes over land (Fig. 7i-a) the summer frequencies are about as high as those during spring which is probably at least partly attributed to biomass burning (Sect. 3.2.1). However, the predominance of either spring or summer in terms of frequency of aerosol episodes is not observed every year. For example, the frequency of strong episodes over land (Fig. 7i-a) is stronger in spring than summer in 2004 and 2005, opposite to the equivalent predominance in spring and summer in previous years. This result highlights the variable behavior of aerosol episodes frequency, which is strongly influenced by factors such as the strength of emission sources or transport and removal processes, which are also determined by synoptic situations and are highly varying from a year to another. This is also shown by the year to year variation in the magnitude of frequency of aerosol events. For example the frequency of strong episodes over land in 2003 is larger than in previous and subsequent years, whereas there is a remarkably large frequency of extreme (spring) episodes over the Mediterranean Sea in 2004. For a complete explanation of the variability of aerosol episodes frequency, an appropriate identification of the aerosol events is necessary, requiring a synergistic use of other aerosol parameters than AOD, which is beyond of the scope of the present study.

The linear regression on the time series of frequency of aerosol episodes reveals a decreasing tendency from 2000 to 2007. This decrease applies for all types of episodes (strong or extreme) and all surface types (land or sea). Note that the largest decrease, decrease, by $36.7 \%$ for strong and by $48.7 \%$ for extreme episodes, is observed over land Mediterranean surfaces. On the contrary, over sea surfaces the decrease in frequency of aerosol episodes is smaller $(-2 \%$ for strong and $-27 \%$ for extreme episodes). The fact that extreme aerosol episodes are mainly attributed to dust transport indicates that probably this transport has become weaker through the period 2000-2007. Our results are in line with a documented decrease in AODs over the Mediterranean basin 

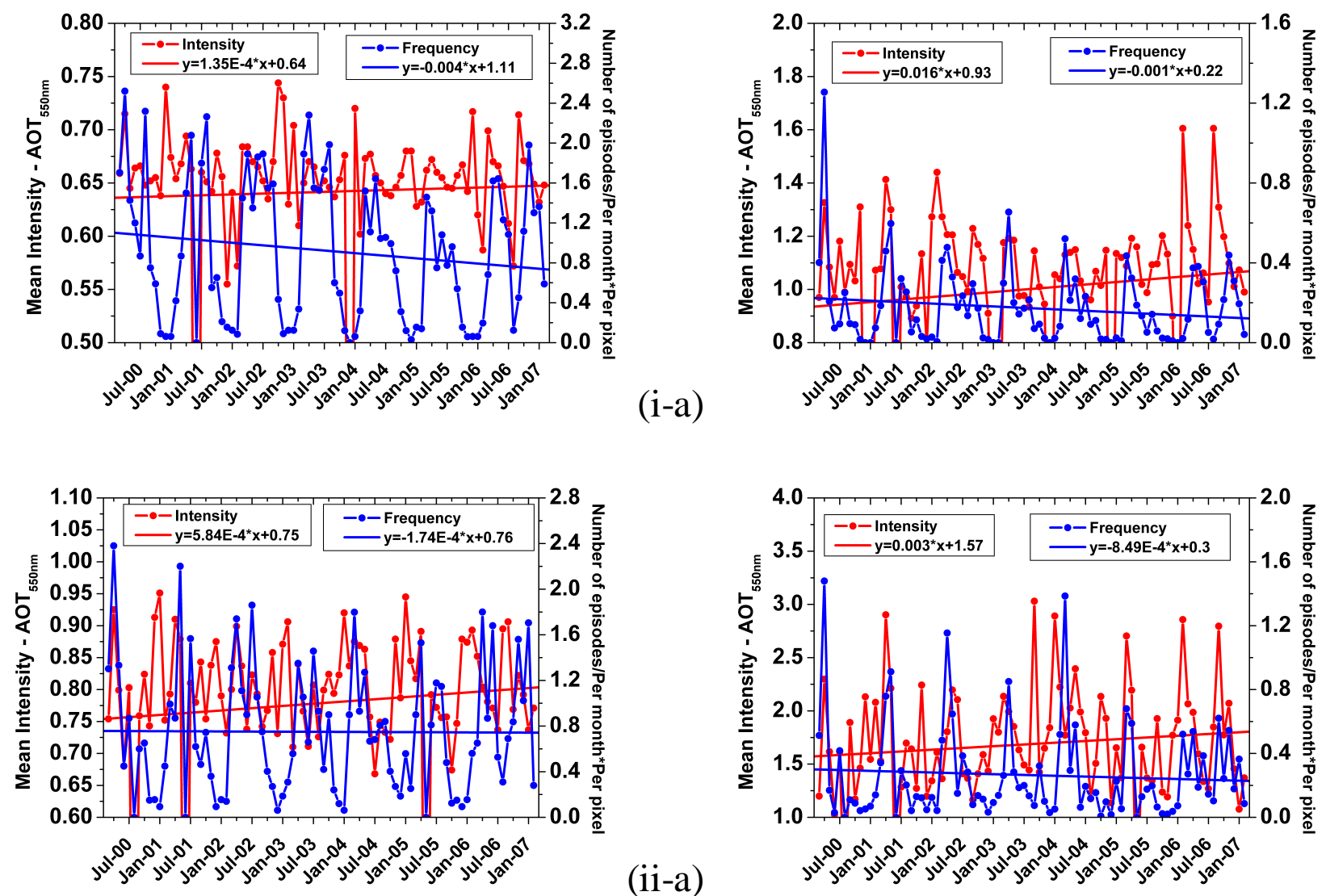

Fig. 7. Inter-annual variation and tendencies of mean intensity (red curves) and frequency (blue curves) of (a) strong, and (b) extreme aerosol episodes over (i) land areas and (ii) sea areas in the Mediterranean basin over the period 2000-2007.

during a similar study period ( -0.04 or $-20.2 \%$, Papadimas et al., 2008). Thus not only mean aerosol loads have decreased in the Mediterranean basin from 2000 to 2007 but also extreme aerosol loads have been also decreasing. On the contrary, the intensity of aerosol events shows an opposite tendency, since for both strong and extreme episodes it has slightly increased from 2000 to 2007. This implies that the Mediterranean basin has undergone less but more intense aerosol episodes during the 7-year period 2000-2007. The reasons of these changes deserve further future investigation.

It has been shown that climate of the greater Mediterranean basin is under the influence of five teleconnection patterns: North Sea Caspian Pattern (NCP), North Atlantic Oscillation (NAO), East Atlantic Pattern (EA), CACO (Central Africa Caspian Oscillation) and Eastern Mediterranean Pattern (EMPI). However, only in case of NAO past studies (e.g. Moulin et al., 1998; Papadimas et al., 2008) have established a link between large-scale circulation and aerosol loads over the study region, showing that the atmospheric transport of dust from North Africa is strongly affected by the North Atlantic Oscillation (NAO). This large-scale climatic control of the dust export is affected by changes in precipitation and atmospheric circulation. Thus, the exis- tence of correlation between NAO (and precipitation) and aerosol events features such as frequency and intensity was investigated. The NAO index (NAOI) data (Hurrell, 1995) were taken from the NOAA NCEP Climate Prediction Center (CPC) Indices, whereas the precipitation data were taken from the Global Precipitation Climatology Project (GPCP) database (Arkin and Xie, 1994; Adler et al., 2003). Time series of the monthly regional mean values of parameters were produced and correlation coefficients between them were computed. The correlation coefficients were found to be small $(R<0.3)$, indicating absence of a clear relationship between NAO or precipitation and aerosol events frequency/intensity. This is probably because in the present study the events are not classified in specific aerosol types, for example dust or biomass burning. NAO is expected to be related with the frequency of dust events only, whereas this correlation is weakened by considering other aerosol type events as well. Indeed, preliminary results of classification of aerosol events into specific types (biomass burning-urban, desert dust, sea-salt, Gkikas et al., 2008) show that correlation coefficients between NAOI and frequency of dust or sea-salt aerosol events are as high as 0.8 . Though the correlation coefficients in the present study are not high, the time 
series of NAOI, precipitation and frequency of aerosol events are consistent in terms of tendencies over the 7-year period. For example, the results (not shown here) show that the decrease in frequency of extreme aerosol events $(-27 \%$ over sea and $-49 \%$ over land surfaces) is associated with an increase in precipitation over the region equal to $5.5 \%$. The increase in precipitation seems to be consistent with the decreasing frequency of aerosol events, since precipitation is one of the stronger (wet) removal processes of atmospheric aerosols (Pruppacher and Klett, 1997). Further work is in progress, with emphasis on specific aerosol types, to clarify the relationships between large scale atmospheric dynamics and tendencies of aerosol events.

\section{Summary and conclusions}

By using aerosol optical depth (AOD) measurements taken with the MODerate resolution Imaging Spectroradiometer (MODIS) instrument from March 2000 to February 2007, aerosol episodes, namely frequency and intensity were investigated in the Mediterranean basin on different temporal and spatial scales. In addition, seasonal and inter-annual variability of aerosol episodes were also examined and their tendencies over the study period were investigated. The major findings of this study can be summarized as follows:

- Extreme aerosol episodes (i.e. episodes with $\left.\mathrm{AOD} \geq \overline{\mathrm{AOD}}+4 \times \sigma_{\mathrm{AOD}}\right)$ were found to be mainly associated with dust. On the other hand strong aerosol events (i.e. episodes with

$\overline{\mathrm{AOD}}+2 \times \sigma_{\mathrm{AOD}} \leq \mathrm{AOD}<\overline{\mathrm{AOD}}+4 \times \sigma_{\mathrm{AOD}} \ldots$ are mainly associated with sea-salt, biomass burning (forest fires) and anthropogenic activities.

- Regarding spatial variability there is a clear difference between the western and eastern parts of the Mediterranean basin, the former being subject more often to aerosol episodes than the latter. In almost all land and sea areas westward of Sardinia and Corsica up to Portugal and Morocco's west coasts 6-14 strong aerosol episodes/year are observed. On the contrary, in the central and eastern parts of the basin no more than 10 strong aerosol episodes/year are observed.

- Aerosol events change also seasonally. The strong episodes occur most frequently in summer whereas the extreme episodes in spring. Moreover, while the most frequent strong episodes (7.3 episodes/year) are observed in the western Mediterranean basin (especially in SE Spain and Alboran basin) extreme aerosol episodes occur most frequently (2.6 episodes/year) in the central and eastern Mediterranean basin. Apart from summer, strong aerosol episodes are also quite often (6 episodes/year) during spring mainly in central and eastern parts of the basin.
- Regarding the intensity of aerosol episodes, a very clear south-to-north gradient was observed highlighting the role of African dust transport on the aerosol episodes features. During the days of strong and extreme aerosol episodes the mean AOD at $550 \mathrm{~nm}$ reaches values of about 1.6 in the Libyan Sea, and 4.1 in the Levantine Sea, respectively, which is due to the proximity of these areas to the dust aerosol source areas (Sahara, Middle-East). Respectively, AOD values over continental areas up to about 1.0 are estimated, which are high enough given the long distance of these areas from (dust) sources.

- Significant inter-annual variability is also observed for both frequencies and intensity of the aerosol events. For instance larger frequencies of strong (summer) episodes over land occurred in 2001, 2002, and 2003 compared to years from 2004 to 2007 . However for a complete explanation of the reasons of the variability of aerosol episodes frequency, a synergistic use of aerosol parameters other than AOD is needed.

- Finally, no statistically significant correlations were found between NAO and precipitation and aerosol events frequency/intensity. The absence of classification of aerosol types in categories such as dust or biomass burning can be the reason as preliminary results show that correlation coefficients between NAOI and frequency of dust or sea-salt aerosol events are as high as 0.8 .

Acknowledgements. The Collection 005 MODIS-Terra and MODIS-Aqua mean monthly data of aerosol optical depth data at $550 \mathrm{~nm}$ were obtained from the NASA-US MODIS Data Processing System (MODAPS) website (ftp://ladsweb.nascom.nasa.gov/). We would like to thank the two reviewers for their comments which help us prepare the revised version. NM acknowledges support by the European Union IP-036961, CIRCE.

Topical Editor F. D' Andrea thanks two anonymous referees for their help in evaluating this paper.

\section{References}

Adler, R. F., Huffman, G. J., Chang, A., Ferraro, R., Xie, P.P., Janowiak, J., Rudolf, B., Schneider, U., Curtis, S., Bolvin, D., Gruber, A., Susskind, J., Arkin, P., and Nelkin, E.: The Version-2 Global Precipitation Climatology Project (GPCP) Monthly Precipitation Analysis (1979-Present), J. Hydrometeorol., 4, 1147-1167, 2003.

Amiridis, V., Balis, D. S., Kazadzis, S., Bais, A., Giannakaki, E., Papayannis, A., and Zerefos, C.: Four-year aerosol observations with a Raman Lidar at Thessaloniki, Greece, in the framework of European Aerosol Research Lidar Network (EARLINET), J. Geophys. Res., 110, D21203, doi:10.1029/2005JD006190, 2005.

Arkin, P. A. and Meisner, B. N.: The relationship between largescale convective rainfall and cold cloud over the western hemisphere during 1982-1984, Mon. Weather Rev., 115, 51-74, 1987. 
Athanassiadou, M., Flocas, H., Harrison, M. A. J., Hort, M. C., Witham, C. S., and Millington, S.: The dust event of 17 April 2005 over Athens, Greece, Weather, 61(5), 125-131, 2006.

Balis, D. S., Amiridis, V., Zerefos, C., Gerasopoulos, E., Andreae, M. O., Zanis, P., Kazantzidis, A., Kazadzis, S., and Papayannis, A.: Raman lidar and sunphotometric measurements of aerosol optical properties during a biomass burning episode over Thessaloniki, Greece, Atmos. Environ., 37, 4529-4538, 2003.

Barnaba, F. and Gobbi, G. P.: Aerosol seasonal variability over the Mediterranean region and relative impact of maritime, continental and Saharan dust particles over the basin from MODIS data in the year 2001, Atmos. Chem. Phys., 4, 2367-2391, 2004, http://www.atmos-chem-phys.net/4/2367/2004/.

Cachorro, V. E., Vergaz, R., de Frutos, A. M., Vilaplana, J. M., Henriques, D., Laulainen, N., and Toledano, C.: Study of desert dust events over the southwestern Iberian Peninsula in year 2000: two case studies, Ann. Geophys., 24, 1493-1510, 2006, http://www.ann-geophys.net/24/1493/2006/.

Chu, D. A., Kaufman, Y. J., Ichoku, C., Remer, L. A., Tanre, D., and Holben, B. N.: Validation of MODIS aerosol optical depth retrieval over land, Geophys. Res. Lett., 29, 8007, doi:10.1029/ 2001GL013205, 2002.

Collaud Coen, M., Weingartner, E., Schaub, D., Hueglin, C., Corrigan, C., Henning, S., Schwikowski, M., and Baltensperger, U.: Saharan dust events at the Jungfraujoch: detection by wavelength dependence of the single scattering albedo and first climatology analysis, Atmos. Chem. Phys., 4, 2465-2480, 2004, http://www.atmos-chem-phys.net/4/2465/2004/.

Dayan, U., Heffter, J., Miller, J., and Gutman, G.: Dust intrusion events into the Mediterranean basin, J. Appl. Meteorol., 30, 1185-1199, 1991.

Gkikas, A., Hatzianastassiou, N., and Mihalopoulos, N.: Study and characterization of aerosol episodes in the Mediterranean basin for the 7-year period 2000-2007 based on MODIS data, European Aerosol Conference, Greece, Thessaloniki, 24-29 August 2008.

Hurrell, J. W.: Decadal trends in the North Atlantic Oscillation: Regional temperatures and precipitation, Science, 269, 676-679, 1995.

Hatzianastassiou, N., Katsoulis, B., and Vardavas, I.: Global distribution of aerosol direct radiative forcing in ultraviolet-visible wavelengths and consequences for the heat budget, Tellus, 56B, 51-71, 2004.

Hatzianastassiou, N., Matsoukas, C., Drakakis, E., Stackhouse Jr., P. W., Koepke, P., Fotiadi, A., Pavlakis, K. G., and Vardavas, I.: The direct effect of aerosols on solar radiation based on satellite observations, reanalysis datasets, and spectral aerosol optical properties from Global Aerosol Data Set (GADS), Atmos. Chem. Phys., 7, 2585-2599, 2007,

http://www.atmos-chem-phys.net/7/2585/2007/.

Husar, R. B., Prospero, J. M., and Stowe, L. L.: Characterization of tropospheric aerosols over the oceans with the NOAA advanced very high resolution radiometer optical thickness operational product, J. Geophys. Res., 102, 16889-16909, 1997.

Husar, R. B., Tratt, D. M., Schichtel, B. A., Falke, S. R., Li, F., Jaffe, D., Gassó, S., Gill, T., Laulainen, N. S., Lu, F., Reheis, M. C., Chun, Y., Westphal, D., Holben, B. N., Gueymard, C., McKendry, I., Kuring, N., Feldman, G. C., McClain, C., Frouin, R. J., Merrill, J., DuBois, D., Vignola, F., Murayama, T., Nick- ovic, S., Wilson, W. E., Sassen, K., Sugimoto, N., and Malm, W. C.: Asian dust events of April 1998, J. Geophys. Res., 106(D16), 18317-18330, 2001.

Ichoku, C., Chu, D. A., Mattoo, S., Kaufman, Y. J., Remer, L. A., Tanré, D., Slutsker, I., and Holben, B. N.: A spatio-temporal approach for global validation and analysis of MODIS aerosol products, Geophys. Res. Lett., 29, 8006, doi:10.1029/2001GL013206, 2002.

Intergovernmental Panel on Climate Change (IPCC): Climate Change 2007: The Physical Science Basis. Summary for Policymakers, Paris, February 2007.

Jacobson, M. Z.: Global direct radiative forcing due to multicomponent anthropogenic and natural aerosols, J. Geophys. Res., 106, 1551-1568, 2001.

Kalivitis, N., Gerasopoulos, E., Vrekoussis, M., Kouvarakis, G., Kubilay, N., Hatzianastassiou, N., Vardavas, I., and Mihalopoulos, N.: Dust transport over the eastern Mediterranean derived from TOMS, AERONET and surface measurements, J. Geophys. Res., 112, D03202, doi:10.1029/2006JD007510, 2007.

Kaufman, Y. J., Tanré, D., Remer, L. A., Vermote, E. F., Chu, A., and Holben, B. N.: Operational remote sensing of tropospheric aerosol over land from EOS Moderate-resolution Imaging Spectroradiometer, J. Geophys. Res., 102, 17051-17065, 1997.

Kaufman, Y. J., Smirnov, A., Holben, B. N., and Dubovik, O.: Baseline maritime aerosol: methodology to derive the optical thickness and the scattering properties, Geophys. Res. Lett., 28, 32513254, 2001.

Kaufmann, Y. J., Tanré, D., and Boucher, O.: A satellite view of aerosols in the climate system, Nature, 419, 215-223, 2002.

Kubilay, N., Cokacar, T., and Oguz, T.: Optical properties of mineral dust outbreaks over the northeastern Mediterranean, J. Geophys. Res., 108(D21), 4666, doi:10.1029/2003JD003798, 2003.

Kukkonen, J., Pohjola, M., Sokhi, R. S., Luhana, L., Kitwiroon, N., Fragkou, L., Rantamäki, M., Berge, E., Ødegaard, V., Slørdal, L. H., Denby, B., and Finardi, S.: Analysis and evaluation of selected local-scale PM10 air pollution episodes in four European cities: Helsinki, London, Milan and Oslo, Atmos. Environ., 39, 2759-2773, 2005.

Lau, K. M., Kim, M. K., and Kim, K. M.: Asian summer monsoon anomalies induced by direct forcing: The role of the Tibetan plateau, Clim. Dynam., 26, 855-864, 2006.

Levy, R. C., Remer, L. A., Tanré, D., Kaufman, Y. J., Ichoku, C., Holben, B. N., Livingston, J. M., Russell, P. B., and Maring, H.: Evaluation of the Moderate-Resolution Imaging Spectroradiometer (MODIS) retrievals of dust aerosol over the ocean during PRIDE, J. Geophys. Res., 108(D19), 8594, doi:10.1029/2002JD002460, 2003.

Levy, R. C., Remer, L. A., and Dubovik, O.: Global aerosol optical properties and application to Moderate Resolution Imaging Spectroradiometer aerosol retrieval over land, J. Geophys. Res., 112, D13210, doi:10.1029/2006JD007815, 2007.

Lohmann, U.: Aerosol effects on precipitation locally and globally, edited by: Brönimman, S., Luterbacher, J., Ewen, T., et al., Climate Variability and Extremes during the past 1000 years, Springer, 2008.

Lyamani, H., Olmo, F. J., and Alados-Arboledas, L.: Saharan dust outbreak over southeastern Spain as detected by sun photometer, Atmos. Environ., 39, 7276-7284, 2005.

Marenco, F., Mazzei, F., Prati, P., and Gatti, M.: Aerosol advec- 
tion and sea salt events in Genoa, Italy, during the second half of 2005, Sci. Tot. Environ., 377, 396-407, 2007.

Meloni, D., di Sarra, A., Monteleone, F., Pace, G., Piacentino, S., and Sferlazzo, D. M.: Seasonal transport patterns of intense Saharan dust events at the Mediterranean island of Lampedusa, Atmos. Res., 88, 134-148, 2008.

Metaxas, D. A. and Bartzokas, A.: Pressure covariability over the Atlantic, Europe and N. Africa. application: Centers of action for temperature, winter precipitation and summer winds in Athens, Greece, Theor. Appl. Climatol., 49, 9-18, 1994.

Millán, M., Salvador, R., Mantilla, E., and Kallos, G.: Photooxidant dynamics in the Mediterranean basin in summer: results from European research projects, J. Geophys. Res., 102, 88118823, 1997.

Moulin, C., Dulac, F., Lambert, C. E., Chazette, P., Jankowiak, I., Chatenet, B., and Lavenu, F.: Long-term daily monitoring of Saharan dust load over ocean using Meteosat ISCCP-B2 data 2. Accuracy of the method and validation using Sun photometer measurements, J. Geophys. Res., 102(D14), 16959-16969, 1997.

Moulin, C., Lambert, C., Dayan, U., Masson, V., Ramonet, M., Bousquet, P., Legrand, M., Balkanski, Y., Guelle, W., Marticorena, B., Bergametti, G., and Dulac, F.: Satellite climatology of African dust transport in the Mediterranean atmosphere, J. Geophys. Res., 103, 13137-13144, 1998.

Niemi, J. V., Tervahattu, H., Vehkamäki, H., Martikainen, J., Laakso, L., Kulmala, M., Aarnio, P., Koskentalo, T., Sillanpää, M., and Makkonen, U.: Characterization of aerosol particle episodes in Finland caused by wildfires in Eastern Europe, Atmos. Chem. Phys., 5, 2299-2310, 2005,

http://www.atmos-chem-phys.net/5/2299/2005/.

Pace, G., Meloni, D., and di Sarra, A.: Forest fire aerosol over the Mediterranean basin during summer 2003, J. Geophys. Res., 110, D21202, doi:10.1029/2005JD005986, 2005.

Papadimas, C. D., Hatzianastassiou, N., Mihalopoulos, N., Querol, X., and Vardavas, I.: Spatial and temporal variability in aerosol properties over the Mediterranean basin based on 6-year (20002006) MODIS data, J. Geophys. Res., 113(D11), D11205, doi:10.1029/2007JD009189, 2008.

Papadimas, C. D., Hatzianastassiou, N., Mihalopoulos, N., Kanakidou, M., Katsoulis, B. D., and Vardavas, I.: Assessment of the MODIS Collections C005 and C004 aerosol optical depth products over the Mediterranean basin, Atmos. Chem. Phys., 9, 2987-2999, 2009,

http://www.atmos-chem-phys.net/9/2987/2009/.

Papayannis, A., Balis, D., Amiridis, V., Chourdakis, G., Tsaknakis, G., Zerefos, C., Castanho, A. D. A., Nickovic, S., Kazadzis, S., and Grabowski, J.: Measurements of Saharan dust aerosols over the Eastern Mediterranean using elastic backscatter-Raman lidar, spectrophotometric and satellite observations in the frame of the EARLINET project, Atmos. Chem. Phys., 5, 2065-2079, 2005, http://www.atmos-chem-phys.net/5/2065/2005/.

Pérez-Marrero, J., Llinás, O., Maroto, L., Rueda, M. J., and Cianca, A.: Saharan dust storms over the Canary Islands during winter 1998 as depicted from the advanced very high-resolution radiometer, Deep-Sea Res. II, 49, 3465-3479, 2002.

Pérez, C., Nickovic, S., Baldasano, J. M., Sicard, M., Rocadenbosch, F., and Cachorro, V. E.: A long Saharan dust event over the western Mediterranean: Lidar, Sun photometer observations, and regional dust modeling, J. Geophys. Res., 111, D15214,
doi:10.1029/2005JD006579, 2006.

Pérez, N., Castillo, S., Pey, J., Alastuey, A., Viana, M., and Querol, X.: Interpretation of the variability of regional background aerosols in the Western Mediterranean, Sci. Total Environ., 407(1), 527-540, 2008.

Pruppacher, H. R. and Klett, J. D.: Microphysics of clouds and precipitation, second revised and enlarged edition with an introduction to cloud chemistry and cloud electricity, 954 pp., Kluwer Academic Publishers, Dordrecht, The Netherlands, 1997.

Ramanathan, V., Crutzen, P. J., Kiehl, J. T., and Rosenfeld, D.: Aerosols, climate, and the hydrological cycle, Science, 294, 2119-2124, 2001.

Remer, L. A., Tanré, D., Kaufman, Y. J., Ichoku, C., Mattoo, S., Levy, R., Chu, D. A., Holben, B., Dubovik, O., Smirnov, A., Martins, J. V., Li, R.-R., and Ahman, Z.: Validation of MODIS aerosol retrieval over ocean, Geophys. Res. Lett., 29(12), 8008, doi:10.1029/2001/GL013204, 2002.

Remer, L. A., Kaufman, Y. J., Tanré, D., Mattoo, S., Chu, D. A., Martins, J. V., Li, R.R., Ichoku, C., Levy, R. C., Kleidman, R. G., Eck, T. F., Vermote, E., and Holben, B. N.: The MODIS aerosol algorithm, products and validation, J. Atmos. Sci., 62(4), 947-973, 2005.

Remer, L., Kaufman, Y., Tanré, D., Mattoo, S., Li, R. R., Martins, J. V., Levy, R., Chu, D. A., Kleidman, R., Ichoku, C., and Koren, I.: Collection 005 Change Summary for MODIS Aerosol (04_L2) Algorithms, http://modis-atmos.gsfc.nasa.gov/ products_C005update.html, 2006.

Remer, L. A. and Kaufman, Y. J.: Aerosol direct radiative effect at the top of the atmosphere over cloud free ocean derived from four years of MODIS data, Atmos. Chem. Phys., 6, 237-253, 2006, http://www.atmos-chem-phys.net/6/237/2006/.

Rodríguez, S., Querol, X., Alastuey, A., and Mantilla, E.: Origin of high PM10 and TSP concentrations in summer in Eastern Spain, Atmos. Environ., 36, 3101-3112, 2002.

Rodríguez, S., Querol, X., Alastuey, A., Viana, M., Alarcón, M., Mantilla, E., and Ruiz, C. R.: Comparative PM10-PM2.5 source contribution study at rural, urban and industrial sites during PM episodes in Eastern Spain, Sci. Total Environ., 328, 95-113, 2004.

Rosenfeld, D., Lohmann, U., Raga, G. B., O’Dowd, C. D., Kulmala, M., Fuzzi, S., Reissell, A., and Andreae, M. O.: Flood or Drought: How do aerosols affect precipitation?, Science, 321, 1309-1313, doi:10.1126/science.1160606, 2008.

Salvador, P., Artíñano, B., Querol, X., and Alastuey, A.: A combined analysis of backward trajectories and aerosol chemistry to characterise long-range transport episodes of particulate matter: The Madrid air basin, a case study. Sci. Total Environ., 390, 495506, 2008.

Sciare, J., Oikonomou, K., Favez, O., Liakakou, E., Markaki, Z., Cachier, H., and Mihalopoulos, N.: Long-term measurements of carbonaceous aerosols in the Eastern Mediterranean: evidence of long-range transport of biomass burning, Atmos. Chem. Phys., 8 , 5551-5563, 2008, http://www.atmos-chem-phys.net/8/5551/2008/.

Sodemann, H., Palmer, A. S., Schwierz, C., Schwikowski, M., and Wernli, H.: The transport history of two Saharan dust events archived in an Alpine ice core, Atmos. Chem. Phys., 6, 667-688, 2006, http://www.atmos-chem-phys.net/6/667/2006/.

Tanré, D., Kaufman, Y. J., Herman, M., and Mattoo, S.: Remote 
sensing of aerosol properties over oceans using the MODIS/EOS spectral radiances, J. Geophys. Res., 102, 16971-16988, 1997.

Toledano, C., Cachorro, V. E., de Frutos, A. M., Sorribas, M., Prats, N., and de la Morena, B. A.: Inventory of African desert dust events over the southwestern Iberian Peninsula in 2000-2005 with an AERONET Cimel Sun photometer, J. Geophys. Res., 112, D21201, doi:10.1029/2006JD008307, 2007.

Tsidulko, M., Krichak, S. O., Alpert, P., Kakaliagkou, O., Kallos, G., and Papadopoulos, A.: Numerical study of a very intensive eastern Mediterranean dust storm, 13-16 March 1998, J. Geophys. Res., 107(D21), 4581, doi:10.1029/2001JD001168, 2002. van der Werf, G. R., Randerson, J. T., Giglio, L., Collatz, G. J., Kasibhatla, P. S., and Arellano Jr., A. F.: Interannual variability in global biomass burning emissions from 1997 to 2004, Atmos. Chem. Phys., 6, 3423-3441, 2006, http://www.atmos-chem-phys.net/6/3423/2006/.

Zhang, P., Lu, N., Hu, X., and Dong, C.: Identification and physical retrieval of dust storm using three MODIS thermal IR channels, Global Planet. Change, 52, 197-206, 2006. 